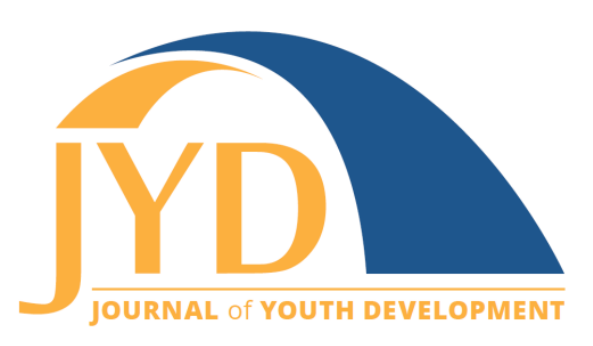

http://jyd.pitt.edu/ | Vol. 16 Issue 5 DOI 10.5195/jyd.2021.1061 | ISSN 2325-4017 (online)

\title{
Promoting Personal Growth in Young People Experiencing Homelessness Through an Outdoors-Based Program
}

\author{
Benjamin John Parry \\ The University of Birmingham, United Kingdom \\ bparry@clemson.edu
}

Janice L. Thompson

The University of Birmingham, United Kingdom

j.thompson.1@bham.ac.uk

Mark J. G. Holland

Newman University, United Kingdom

mark.holland@staff.newman.ac.uk

\section{Jennifer Cumming}

The University of Birmingham, United Kingdom

j.cumming@bham.ac.uk

\begin{abstract}
Outdoors-based youth development programs demonstrate the efficacy to improve indicators of personal growth and mental health in a range of disadvantaged young people. However, the most marginalized young people in society, who stand to benefit the most from such initiatives, remain underrepresented in the research. My Strengths Training for Life (MST4Life) is a positive youth development (PYD) intervention for young people experiencing homelessness that incorporates a life skills program and an outdoor adventure education (OAE) course. The current study presents a qualitative investigation of the OAE course to understand its role in promoting positive changes for participants. Reflexive thematic analysis led to the development of inductively driven themes which were conceptualized based on relevant theories (e.g., relational developmental systems) and models (e.g., 5 Cs of PYD). Findings highlight the benefits of a preceding life skills program to psychologically prepare participants to thrive in the unfamiliar setting of the outdoors and related challenges. During the course, adaptive developmental regulations supported participants' basic psychological needs and fostered personal growth.

Improvements in social competence was a common theme across participants and played a pivotal role in facilitating balanced development across the 5 Cs. In addition, experiences during the course promoted indicators of mental health and intentions to make positive lifestyle changes. Implications of these findings are discussed in relation to making outdoors-based youth development courses more accessible
\end{abstract}

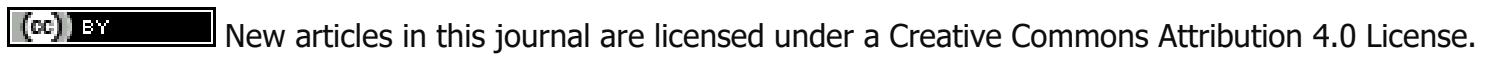
This journal is published by the University Library System, University of Pittsburgh and is cosponsored by the University of Pittsburgh Press. The Journal of Youth Development is the official peer-reviewed publication of the National Association of Extension 4-H Youth Development Professionals and the National AfterSchool Association. 


\section{Promoting Personal Growth}

for marginalized young people, as well as how OAE and PYD programs can add value to the youth homeless sector.

Key words: outdoor adventure education, positive youth development, personal growth, mental health, young people experiencing homelessness

\section{Introduction}

Outdoors-based youth development programs can promote personal growth and well-being in disadvantaged young people (Bowen \& Neill, 2016; Bowers et al., 2019; Mercier et al., 2019; Norton \& Watt, 2014). However, for those who stand to benefit the most from such interventions, such as young people experiencing homelessness, ${ }^{1}$ outdoors-based youth development programs appear to be underutilized (for a review, see Morton et al., 2020). In part, this can be explained by the prevalence of homelessness in young people during later adolescence and early adulthood (ages 16 to 25 years; Morton et al., 2018), and the sparsity of evidence for positive youth development (PYD) and outdoors-based programs for young people during these developmental periods (for reviews, see Parry et al., 2021a; Mygind et al., 2019; Tillmann et al., 2018). However, outdoors-based youth development programs may present an effective solution to many health inequalities and complex support needs faced by young people experiencing homelessness (Harper et al., 2019; Homeless Link, 2018).

Although outdoors-based youth development programs are not clearly defined, the complementary styles of working with young people in outdoor adventure education (OAE; Hattie et al., 1997) and PYD (Damon, 2004) are well documented (Sibthorp \& Morgan, 2011). For instance, guidelines for PYD programs emphasize the importance of positive youth-adult relationships, leadership opportunities, feeling safe and secure, and providing skills-building activities (Eccles \& Gootman, 2002; Lerner et al., 2005). OAE courses capture many of these core components, with evidence suggesting empowering, supportive, and rapport-building climates in adventure programs facilitate positive developmental outcomes (Bowers et al., 2019; Sibthorp et al., 2007). To understand the role of OAE courses in fostering positive outcomes, relational developmental systems is considered an appropriate theoretical framework (Sibthorp \& Morgan, 2011).

Relational developmental systems theory proposes that young people's development derives from personal strengths and ecological assets (Lerner \& Overton, 2008). Developmental regulations are the bidirectional relations between young people and their broader ecologies

${ }^{1}$ Young people experiencing homelessness also include those at risk (e.g., insecure housing, seeking local authorities for support; Homeless Link, 2018). 


\section{Promoting Personal Growth}

that shape developmental trajectories (Brandtstädter, 2006). When developmental regulations are adaptive (i.e., mutually beneficial relations), young people experience positive developmental outcomes and longer-term benefits, such as reduced risk behaviors and depression and greater contribution to wider communities (Lerner et al., 2005; Lerner et al., 2011). Programs that create adaptive developmental regulations can address mental health inequalities in young people experiencing homelessness, including reducing risk of substance use and depression and enhancing feelings of connectedness (Edidin et al., 2012; Rice et al., 2012). In outdoors-based programs, adaptive developmental regulations are facilitated through the natural outdoor setting and participants being equipped with psychosocial skills to adaptively engage in team-based activities (Sibthorp et al., 2007; Sibthorp \& Morgan, 2011). For disadvantaged groups, experiencing a sense of belonging and developing social skills have been identified as key features of OAE courses to promote personal growth and mental health benefits (Bowen \& Neill, 2016; Bowers et al., 2019)

Through the lens of PYD, personal growth can be understood as development in the domains of competence, connection, confidence, caring, and character, known as the five CS of PYD (definitions provided in Table 1; Lerner et al., 2003; Roth \& Brooks-Gunn, 2003). Youth who experience adaptive developmental regulations are likely to exhibit development across the five Cs (Lerner et al., 2005). PYD evaluations of outdoors-based programs suggest the outdoor setting (e.g., connection with nature) and OAE activities (e.g., team building, leadership opportunities) can promote the five Cs in marginalized groups (Bowers et al., 2019; Mercier et al., 2019). Additionally, the five Cs reflect psychosocial and life skills that have been linked with mental health benefits for disadvantaged young people taking part in wilderness-based interventions (Bowen \& Neill, 2016; Harper et al., 2019). In young people from rural communities, quantitative evidence suggests links between connection with nature, the five Cs, and mental health benefits (Bowers et al., 2021). In other settings, the five Cs have been linked with indicators of mental health, such as resilience, life satisfaction, and well-being in older adolescents and young adults from a range of socioeconomic communities (Forrest-Bank et al., 2015; Holsen et al., 2016). 
Promoting Personal Growth

Table 1. Definitions of the Five Cs of Positive Youth Development and Their Application in an Outdoor Setting

\begin{tabular}{|c|c|c|}
\hline Five Cs & Standardized definition & Application in outdoor setting \\
\hline Competence & $\begin{array}{l}\text { "Positive view of one's actions in domain specific areas } \\
\text { including social, academic, cognitive, and vocational. Social } \\
\text { competence pertains to interpersonal skills (e.g., conflict } \\
\text { resolution). Cognitive competence pertains to cognitive abilities } \\
\text { (e.g., decision making). School grades, attendance, and test } \\
\text { scores are part of academic competence. Vocational } \\
\text { competence involves work habits and career choice } \\
\text { explorations" (Lerner et al., 2005; p. 23). }\end{array}$ & $\begin{array}{l}\text { - Outdoor activities can promote physical competence. } \\
\text { - Team-based, outdoor activities and challenges can promote social } \\
\text { competence. } \\
\text { - "Experiencing and completing new activities can assist in } \\
\text { identifying possible career options, promoting vocational } \\
\text { competence" (Mercier et al., 2019; p. 43). } \\
\text { - "Preparation for, completion of, and reflection on, activities can } \\
\text { promote cognitive competence" (Mercier et al., 2019; p. 43). }\end{array}$ \\
\hline Confidence & $\begin{array}{l}\text { "An internal sense of overall positive self-worth and self- } \\
\text { efficacy; one's global self-regard, as opposed to domain specific } \\
\text { beliefs" (Lerner et al., 2005; p. 23). }\end{array}$ & $\begin{array}{l}\text { - Participation and feelings of success in outdoor activities can } \\
\text { promote feelings of accomplishment (Mercier et al., 2019). }\end{array}$ \\
\hline Connection & $\begin{array}{l}\text { "Positive bonds with people and institutions that are reflected } \\
\text { in bidirectional exchanges between the individual and peers, } \\
\text { family, school, and community in which both parties contribute } \\
\text { to the relationship" (Lerner et al., 2005; p. 23). }\end{array}$ & $\begin{array}{l}\text { - "Support from the coordinating teacher can nurture feelings of } \\
\text { connection with the teacher" (Mercier et al., 2019; p. 43). } \\
\text { - "Strengthened peer connections through group-based outdoor } \\
\text { challenges" (Mercier et al., 2019; p. 43). }\end{array}$ \\
\hline Characters & $\begin{array}{l}\text { "Respect for societal and cultural rules, possession of standards } \\
\text { for correct behaviors, a sense of right and wrong (morality), } \\
\text { and integrity" (Lerner et al., 2005; p. 23). }\end{array}$ & $\begin{array}{l}\text { - Respect for oneself, others, property, and community developed } \\
\text { through all aspects of the challenge (Mercier et al., 2019; p. 44). }\end{array}$ \\
\hline Caring & $\begin{array}{l}\text { "A sense of sympathy and empathy for others" (Lerner et al., } \\
\text { 2005; p. 23). }\end{array}$ & $\begin{array}{l}\text { - Showing peer support during team-based activities can promote } \\
\text { feelings of empathy for others (Mercier et al., 2019). }\end{array}$ \\
\hline Contribution & $\begin{array}{l}\text { "A young person enacts behaviors indicative of the Five Cs by } \\
\text { contributing positively to self, family, community, and, } \\
\text { ultimately, civil society" (Lerner et al., 2005; p. 23). }\end{array}$ & $\begin{array}{l}\text { - "Young people may become more involved in the school or } \\
\text { broader community due to programme experiences" (Mercier et } \\
\text { al., 2019; p. 44). }\end{array}$ \\
\hline
\end{tabular}




\section{Promoting Personal Growth}

Existing evidence suggests the five Cs play an important role in supporting young people's mental health. Moreover, outdoors-based programs are an effective approach to creating adaptive developmental regulations that nurture personal growth in marginalized groups. However, there are gaps in the existing literature. For example, links between the outdoor setting, the five CS of PYD, and mental health benefits are yet to have been explored in structured OAE-based programs or from a qualitative perspective. Additionally, research that explores the impact of OAE-based youth development programs for more diverse samples of young people is required, specifically, older young people experiencing severe social disadvantage. The present study addressed these gaps in the literature by conducting a theoryinformed evaluation of an OAE course for young people experiencing homelessness. The OAE course investigated was part of the My Strengths Training for Life (MST4Life) program.

MST4Life is a community-based PYD program that consists of two phases: Phase 1 is comprised of 10 life skills workshops and Phase 2 consists of a 3- to 4-day ${ }^{2}$ OAE course. (For a more detailed overview of MST4Life, see Parry et al., 2021b.) Quantitative evidence highlights that participants report significant improvements in perceptions of resilience and well-being after taking part in Phase 1 of the program (Quinton et al., 2021). However, it is not known if the OAE course elicits similar mental health benefits. From a qualitative perspective, the OAE course is considered to support the development of psychosocial outcomes (e.g., intra- and interpersonal competence; Parry et al., 2021b). By utilising the five Cs framework, the present study provides a developmental understanding of participants' personal growth as a result of taking part in the OAE course.

Additionally, it is still not fully understood how the OAE course contributes to participants' development. For instance, the delivery of MST4Life is informed by self-determination theory (SDT) to create a program atmosphere supporting participants' basic psychological needs (Ryan \& Deci, 2000; Tidmarsh et al., 2021). Whilst this approach is consistently delivered across both phases (Tidmarsh et al., 2021), the extent to which a needs-supportive climate shapes the participants' experiences of the OAE course remains unknown. In studying the program through the lens of SDT and relational developmental systems, the current study applies a multi-theory approach to exploring the role of a need supportive climate in creating unique adaptive developmental regulations for MST4Life participants during the OAE course.

\footnotetext{
${ }^{2}$ Due to this study evaluating a series of OAE courses over a 5-year period, the length of the course varied for some participants. Those taking part in the pilot program experienced a 3-day course $(n=11)$ and the rest of the study sample took part in a 4day course $(n=43)$
} 


\section{Promoting Personal Growth}

This study aimed to understand the impact of MST4Life's OAE course on participants' personal growth and mental health. A qualitative investigation of participants' experiences was conducted to explore the extent to which the course fostered adaptive developmental regulations (i.e., ecological assets and strengths of participants), and promoted personal growth (i.e., the five Cs of PYD) and indicators of mental health (i.e., well-being and resilience). In doing so, this study provides new insights into the impact of OAE-based programs in diverse groups and evaluates a novel intervention approach for addressing health inequalities in young people experiencing homelessness.

\section{Methods}

\section{The OAE Course (Phase 2 of MST4Life)}

The residential OAE course was delivered in partnership by OAE instructors and MST4Life facilitators. OAE instructors took a lead role in delivering outdoor activities, including canoeing, raft building, a mountain hike, high and low ropes courses, mountain biking, and caving. Teambased, structured reflections, which took place after activities and during morning meetings, were jointly led by the MST4Life facilitators and OAE instructors. Structured reflections were designed to help participants recognize achievements, set personal and team goals, and engage in constructive, group-based problem-solving. Evenings were used for data collection as participants are invited to take part in an interactive diary room answering questions to guide their personal reflections of the trip.

\section{Procedure}

Study participants were recruited from different cohorts of MST4Life over a 5-year period (2014-2019). To be eligible to take part in the study, participants were required to have attended and engaged in Phase 1 of MST4Life (psychoeducational program) and provided informed consent. A total of 113 MST4Life participants were eligible for the current study; from this sample, 54 participants took part in data collection (diary room entry, outlined below), making up the study sample. Participating in the data collection was optional and reasons for not partaking were not recorded. An independent sample $T$-test revealed no significant differences $(p<.05)$ for posttest (end of Phase 1 of MST4Life and before OAE course) scores for resilience, self-worth, engagement, well-being, connectedness, and enjoyment between those who did and did not complete a diary room entry during the OAE course (for more details of measures, see Quinton et al., 2021).

Study participants ranged from 16 to 24 years old $(M=19.43 ; S D=2.18)$ and the majority identified as male (58.7\%); one participant identified as transgender. The different ethnicities 


\section{Promoting Personal Growth}

represented in the sample were: White British (61.9\%), multiple or mixed ethnic groups (21\%), Asian (4.8\%), Black (4.8\%) or other (4.8\%). Time spent living within the housing organization before taking part in MST4Life ranged from 1 week to 14 months ( $M=5.5$ months; $S D=3.8$ months). At the time of completing demographic information, support needs were recorded as: unemployed (38\%), full-time education (28.6\%), in a sponsored training program (14.3\%), unable to work $(14.3 \%)$, and part-time employment (4.8\%). Of those who responded to the question ( $n=35), 57 \%$ of participants reported having a learning difficulty. While participants' mental health status was not recorded, recent U.K. data suggests $35 \%$ of young people experiencing homelessness are likely to have mental health issues (Homeless Link, 2018).

\section{Data Collection}

Participants were invited to participate in semi-structured diary rooms-a method of data collection designed to be informal, engaging, and facilitate reflective practice for participants (Cooley et al., 2014). Diary rooms could be completed in different ways to give participants more autonomy during the data collection process. The typical format of the diary room involved participants individually reflecting on a series of questions without an interviewer and in front of a camera $(n=29)$. Alternatively, participants could opt to have a researcher present to ask questions $(n=14)$ or give handwritten responses $(n=3)$. The lead researcher (trained in qualitative research methods) conducted all diary rooms when participants requested that a researcher ask the questions. The researcher would ask as few probing questions as possible to ensure consistency of questions asked (and answered). The questions were open-ended, strengths-based (i.e., solution- and future-focused), and structured using the Kirkpatrick model of evaluation (i.e., reaction, learning, behavior and results; Kirkpatrick, 1994).

\section{Positionality}

The lead author's research philosophy was informed by principles of transformative paradigm and pragmatism (Feilzer, 2010; Mertens, 2007; Morgan, 2014). As such, the purpose of the research was tethered to overarching aims of social justice and addressing real-world problems (Romm, 2014). The research process also adhered to both paradigms' core values of adopting a participatory approach to data collection. When analyzing data, the lead researcher adhered to interpretivist principles (Berry et al., 2002; Levitt et al., 2017); that is, findings were constructed from the narratives and stories of participants, as well as the experiences and knowledge of the researcher through a process of reflexive thematic analysis (Braun \& Clarke, 2019). 


\section{Promoting Personal Growth}

\section{Data Analysis}

All diary room entries were transcribed verbatim. Data were thematically analyzed in an iterative process involving data familiarization and immersion, deductive coding of raw data into first-order themes, and the generation of data-driven, lower-order themes (Braun \& Clarke, 2006). During this process, themes were considered to be "stories about particular patterns of shared meaning across the dataset" (Braun \& Clarke, 2019, p. 592); as such, themes were not measured by a percentage of representation but were required to be reflective of a shared narrative across participants.

Building upon their 2006 template for thematic analysis (Braun \& Clarke, 2006), Braun \& Clarke (2019) advocate for reflexive thematic analysis, in which the researcher actively acknowledges and embraces their role in the construction of themes as well as the research process itself. From this interpretivist stance, the value of qualitative data can be determined by its trustworthiness (e.g., reflective positionality statements) as opposed to more positivist parameters (e.g., inter-rater reliability; Smith \& McGannon, 2018). To enhance the trustworthiness and sincerity of reflexive thematic analysis, and qualitative research more broadly, it is essential for a researcher to reflect upon their positionality within the research (Braun \& Clarke, 2019; Nowell et al., 2017; Tracy, 2010). The lead author has provided a reflexive positionality statement in the Appendix.

The rigor and trustworthiness of the analytic procedure were also enhanced through the use of critical discussions, a process encouraged in qualitative research to critique the researcher's interpretation of data (Smith \& McGannon, 2018). Critical discussions were held with the wider research team who were familiar with MST4Life and had experience conducting qualitative data analysis, as well as researchers who were experienced in qualitative research but knew less about MST4Life. Conducting critical discussions with varied research colleagues offers a broader critique of how knowledge is constructed and strengthens the rigor of the analytic process (Smith \& McGannon, 2018). Finally, triangulating multiple views of participants over a 5-year period through a theory-informed lens served to enrich detailed descriptions of themes and strengthen their credibility (Barbour, 2001; Nowell et al., 2017; Tracy, 2010).

\section{Results}

The purpose of this section is to convey the narrative of participants' experiences during the OAE course, with particular emphasis on understanding how, if at all, adaptive developmental regulations were created, and the impact of the course on indicators of personal growth and mental health. Theory-informed themes acted as a framework to identify patterns across 


\section{Promoting Personal Growth}

participants' experiences, leading to inductively constructed subthemes (full descriptions of themes can be found in Table 2).

\section{Adaptive Developmental Regulations}

The theme of adaptive developmental regulations captured mutually beneficial relations between ecological assets of the OAE course (e.g., being removed from everyday norms and experiencing challenges, team-based activities, and needs-supportive climate) and the strengths of participants (e.g., psychosocial skills gained in Phase 1 of MST4Life, sense of optimism). Ecological assets reflected core components of the OAE course that participants saw as influential in fostering personal growth, promoting indicators of mental health, and facilitating the potential for longer-term change. The participants' strengths were considered important personal constructs that facilitated positive engagement with ecological assets. The resulting adaptive developmental regulations are best described in two subthemes: (a) When we are challenged and supported, we grow, and (b) In being far removed from everyday norms, a sense of escapism and peacefulness can be found.

\section{When We Are Challenged and Supported, We Grow}

Participants' journeys of personal growth through the course appeared to be driven by mutually beneficial relations between challenges, a needs-supportive climate, and psychosocial skills developed during Phase 1 of MST4Life. Specifically, participants discussed the OAE instructors' role in creating a needs-supportive climate through a challenge by choice approach (Russell \& Bisson, 2003). An autonomy- and competence-supportive approach by the instructors enabled all participants to engage in activities and experience a personal sense of challenge, "They [OAE instructors] know that everyone's different and they know that everyone has different comfort zones" (Participant 1). Participants experienced feelings of autonomy through having a sense of personal responsibility for the level of challenge they embraced. And feelings of relatedness were nurtured through experiences of overcoming fears with the support of staff and peers, "I used to be nervous, but the help of my friends and staff, they've encouraged me a lot to do it" (Participant 2). A relatedness-supportive atmosphere also encouraged participants to apply the social skills they had developed in Phase 1 resulting in participants working effectively in teambased challenges, "Learning to be more of a team player has come into help here [OAE course], so I know what to do and I helped people" (Participant 3). 
Table 2. Definitions of Data-Driven Themes

\begin{tabular}{|c|c|c|}
\hline $\begin{array}{l}\text { First-order theme } \\
\text { (deductive) }\end{array}$ & Sub-theme (inductive) & Definition \\
\hline \multirow[t]{2}{*}{$\begin{array}{l}\text { Adaptive } \\
\text { developmental } \\
\text { regulations }\end{array}$} & $\begin{array}{l}\text { When we are challenged and } \\
\text { supported, we grow. }\end{array}$ & $\begin{array}{l}\text { Challenges during the OAE component provided participants with opportunities to grow } \\
\text { in the five Cs. Equally as important was the process of being supported through } \\
\text { challenges (by peers, staff, and instructors), which gave participants the confidence to } \\
\text { embrace new experiences and stretch their comfort zone. }\end{array}$ \\
\hline & $\begin{array}{l}\text { In being far removed from everyday } \\
\text { norms, a sense of escapism and } \\
\text { peacefulness can be found. }\end{array}$ & $\begin{array}{l}\text { In the outdoor setting, participants were far removed from their everyday norms; by } \\
\text { embracing this change of scene with optimism, participants were able to experience a } \\
\text { sense of escapism and peacefulness during the OAE course. }\end{array}$ \\
\hline Personal growth & $\begin{array}{l}\text { Social competence-the fertile soil } \\
\text { for versatile growth }\end{array}$ & $\begin{array}{l}\text { This theme reflects the importance of social competence, which, in the data, was } \\
\text { reflected in the ability to adaptively apply social skills in different situations. The } \\
\text { versatile growth reflects how this core indicator of PYD permeates and facilitates } \\
\text { growth in the other Cs (e.g., socially competent participants contributed to group } \\
\text { activities, demonstrating a balance of intrapersonal confidence and socio-emotional } \\
\text { awareness of peers). }\end{array}$ \\
\hline \multirow[t]{2}{*}{$\begin{array}{l}\text { Indicators of longer- } \\
\text { term change }\end{array}$} & $\begin{array}{l}\text { It's more than just climbing a } \\
\text { mountain-fostering positive mental } \\
\text { health in the outdoors }\end{array}$ & $\begin{array}{l}\text { Participants' narratives reflected the mental health benefits that can be fostered from } \\
\text { engaging with the outdoor setting; for instance, the natural environment promoted } \\
\text { feelings of well-being, whilst challenging outdoor activities fostered a sense of } \\
\text { resilience. }\end{array}$ \\
\hline & $\begin{array}{l}\text { Changes in attitudes and } \\
\text { intentions-the potential for } \\
\text { sustained change }\end{array}$ & $\begin{array}{l}\text { In the absence of follow-up data, this theme reflects how young people's experience in } \\
\text { the outdoors had a profound effect on their outlook on the world, their attitudes } \\
\text { towards their peers, their aspirations for the future, and intentions to put in place } \\
\text { meaningful changes when they return home from the course. }\end{array}$ \\
\hline
\end{tabular}




\section{Promoting Personal Growth}

Challenges were not only present during the outdoor activities but also arose from the residential aspect of the course. For instance, some participants found living in close proximity with different people socially challenging; however, attending Phase 1 of MST4Life helped them to adapt to the social conditions: "Through the 10 weeks of the training [Phase 1 of MST4Life] ... I wasn't always around people that were my friends, but it's learning to adapt and support them anyway because we're here as a team" (Participant 4). Entering into the course with more effective psychosocial skills to work and cohabit with each other meant participants also contributed to the relatedness-supportive climate through building a sense of community and social cohesion, "The atmosphere in the group is just like really tight and get on really well . . . if one of us feels down ... we all go and check on them" (Participant 5).

\section{In Being Far Removed From Everyday Norms, a Sense of Escapism and Peacefulness} Can be Found

Mutually beneficial relations between being removed from everyday norms and participants' sense of optimism underpinned positive experiences during the course, "It's very rarely that as a city girl you get to come to somewhere like this and experience what we have. So, why miss out on that opportunity?" (Participant 4). This extract reflects a common outlook of enthusiasm and sense of adventure when embarking upon the course, as participants saw the experience as a "chance to get away" (Participant 6). Indeed, the course was designed to promote skill development; however, having new experiences in the outdoors and connecting with nature were features of the course that participants saw as beneficial for their own and others' wellbeing, "I think coming here will give a lot of people a peaceful state of mind, because being in the city, everything's all fast-paced, everyone's rushing everywhere" (Participant 7).

Recognizing the therapeutic benefits of the outdoor setting was a common pattern across participants; exemplified by one participant who spoke of feeling a sense of "peace and sanctuary" (Participant 8), which they struggled to find in their home living conditions. For a group of young people accustomed to an urban environment, some having never left their home city, embracing their new surroundings with a sense of optimism promoted engagement in activities, and maximized their potential to experience personal growth.

\section{Personal Growth}

The theme of personal growth describes how adaptive developmental regulations during the OAE course promoted the five Cs of PYD. In particular, participants' experiences demonstrated a pattern of social competence underpinning development in other domains. Social competence involved participants adaptively applying social skills to help themselves and others thrive. The 


\section{Promoting Personal Growth}

social skill of giving and receiving social support, for example, was pertinent in participants' narrative of personal growth,

Rock climbing was really good. It was nice to help someone up there and know they've accomplished something and faced their fears, it was good to know that I helped them do that. That was better than me actually doing it myself. (Participant 9)

Embracing leadership opportunities through team-based activities embedded within a broader need supportive climate resulted in participants' demonstrating balanced development across the five Cs, exemplified through improvements in confidence and awareness of socioemotional needs of others (caring and character). This was poignantly reflected by Participant 10, who recognized there was more to leadership and teamwork than "just giving orders." The participant also saw the value of being considerate of others, which promoted changes in ways they engaged in team-based activities, "I've done more caring, I haven't put myself first like I usually do, I've thought of other people around me" (Participant 10).

Growing in their capacity to care, support, and work effectively with each other, participants thrived in outdoor activities, reflected through feelings of personal and team accomplishments. In the process of achieving goals, participants spoke of how their sense of self-belief (confidence) grew through experiencing support from their peers, "They said . . 'you can actually do it and we know you can and please don't give up'. I was like, wow, my group actually believes in me" (Participant 11). During challenging activities, peer support was frequently seen as a source of boosting self-esteem and feelings of competence, with no recorded data suggesting social support was perceived as peer pressure. This indicates participants were learning to give social support appropriately and, in turn, contributing to a needs-supportive climate through being more caring and feeling more connected with others,

My attitude against people is gonna change, you know, give people a chance and help people more if they're struggling rather than just leaving them . . . encourage them, help them. (Participant 12)

Applying social skills to self-regulate thoughts and behaviours helped participants function effectively in activities and experience a balanced development across the five Cs. For instance, as participants demonstrated more effective listening and communication skills, they also showed more respect for each other (character), "You have to be respectful when approaching certain matters . . . instead of you talking all the time, just sit back and get them to observe the environment, just get a feel how to manage certain situations" (Participant 13). Effective 


\section{Promoting Personal Growth}

communication in team activities also fostered feelings of confidence and connection, especially for more reserved members of the group:

Normally I'm just a person who sits in the back of the room and just won't be heard, but ... I've got to know everyone, I've got really like, got like a little connection with a few people. . . we're working together, we're taking each other's opinions. (Participant 10)

Improved social competence laid the foundations for participants to feel more connected with staff too. This was particularly evident with housing staff, who participants frequently saw as adults who supported them in managing the complexities in their home lives. However, when taking part in the outdoor activities together, participants had the rare experience of supporting staff, experiencing a shift in their role from being the "helped" to the "helper." This process broke down views and expectations of "the other," serving to empower participants and promote positive adult-youth relationships:

Not a barrier at all between staff and residents, it was more like a natural division, but as the days have gone that's like started to completely disappear and I think that's because a lot of the young people have realized that we're not different. (Participant 4)

\section{Indicators of Longer-Term Change}

The final theme described how participants' experiences demonstrated potential longer-term changes, such as indicators of mental health (e.g., well-being and resilience) and the sixth C of contribution (e.g., changes in intentions and attitudes). Two subthemes were constructed: (a) It's more than just climbing a mountain-fostering positive mental health in the outdoors, and (b) changes in intentions and attitudes - the potential for sustained change.

\section{It's More Than Just Climbing a Mountain-Fostering Positive Mental Health in the Outdoors}

This subtheme reflects improvements in feelings of well-being and resilience facilitated through engaging in the outdoor setting and activities. The mountain hike, in particular, was seen by participants as the "pinnacle" of the course as they prepared to scale the second largest peak in the area. Subsequently, the activity was most frequently referenced for its sense of challenge and achievement (both mental and physical), providing meaningful experiences, and often seen as the catalyst for change. 


\section{Promoting Personal Growth}

It's made me realize I'm actually a lot stronger than I thought I was, both physically and mentally, in the sense that I climbed a mountain today and I didn't think I'd ever be physically able to do that . . . I think that was a test of mental strength more than anything, like determining if it was worth it or not, going through physical pain to get that sense of accomplishment, and it was. (Participant 4)

Climbing the mountain instilled physical competence, leading to a sense of pride and personal fulfilment. As a result, participants started to view themselves in a more positive light, "My mindset has changed, before I used to always give up, but now I have learned determination, I've learned to prepare within myself and just try my best" (Participant 14). As depicted in this extract, participants identified with feelings of resilience in overcoming challenges and recognizing achievements beyond their expectations; when reflected upon, these experiences were often seen as powerful life lessons,

I've learned that no matter how big a task, a mountain ... if you've got enough desire and will to tell yourself to do it or to tell yourself to take each step, and one foot after another, then I'm pretty sure you're gonna be alright with other things in life really . . . train yourself to be mentally resistant in hard tasks. (Participant 15)

Participants' perceptions of self-worth and resilience after achieving personal and team accomplishments were closely linked to well-being. This was exemplified in feelings of social well-being, reflected through a sense of belonging with peers and personal well-being, interpreted from expressions of satisfaction, enjoyment and a sense of reconnection with one's self:

I've learnt how to be myself again because I was never really me, I never really did the things that I like to do, like climbing rocks, going in the water, doing all the stuff that I like to do. (Participant 16)

\section{Changes in Intentions and Attitudes-The Potential for Sustained Change}

Experiences during the course also shaped participants' desires to make changes when returning home, reflected through intentions to make positive contributions to themselves and others. These intentions stemmed from changes in how participants viewed themselves and those around them, and the potential for longer-term change underpinned by many participants identifying with intrinsically driven motivations. 


\section{Promoting Personal Growth}

I think that's kinda made me re-evaluate and recognize as well my own capabilities . . . it's really like affirmed within me that I don't want to be defined by my fears . . . I want to keep pushing myself. (Participant 4)

For this participant, their intrinsic drive was also reflected in their desire to adopt a healthier lifestyle following the OAE course: "make a conscious effort to eat a more healthy diet, drink more water . . . just do a bit more exercise because the feeling afterwards, I felt amazing" (Participant 4). Outdoor activities enabled young people to engage with physical activity in a novel way, prompting them to question their preconceived notions of what it means to be physically active and healthy. A similar process was observed when engaging with nature; at first young people were cautious and, in some cases, reluctant. However, towards the end of the course, many participants spoke of appreciating the mental and physical benefits of spending time in the outdoors and expressed their intention to make more conscious efforts to engage with nature when they returned home:

I will go out more, like find more places like this . . . I'm calmer here, so I think when I get back to [home] I'm gonna try and maintain that calmness . . . go out on an adventure and have more breaks away. (Participant 17)

Indeed, many participants experienced socio-emotional benefits during the course, including a sense of calm and peacefulness from being in the natural environment. The course also helped participants change their perceptions of how they interact and work with new people; with participants recognizing transferability of the social skills they had developed and identified areas in their lives where they could be applied:

Once I go from here I can take all this sort of, communication skills, teamwork all this put it into real life, go into to work, how to make friends, and how to communicate with people and having respect to one and other. (Participant 18)

Participants demonstrated an awareness of how social skills could be applied in other settings and intentionality to do so. Moreover, their narratives also reflected more subtle changes in social attitudes that could be transferred beyond the course. For instance, positive social dynamics during the course contributed to challenging participants' preconceptions and expectations of others: "I always just assume people are going to be horrible until you get to know them. And all of these people are nice when you get to know them" (Participant 19). Breaking down negative social expectations helped participants understand each other and work more effectively as a team. These positive social experiences appeared to leave a long- 


\section{Promoting Personal Growth}

lasting impression on participants, fostering social attitudes and behaviors that were more empathetic and compassionate,

My attitude against people is gonna change, give people a chance and help people more if they're struggling rather than just leaving them . . . Encourage them, help them. I'm gonna bring that with me definitely. (Participant 20)

\section{Discussion}

This study was an investigation into the impact of an OAE course on indicators of personal growth and mental health for young people experiencing homelessness. Participants' narratives depicted a story through which development in the five Cs emanated from feeling socially competent, most typically reflected in experiences of giving and receiving social support. Participants were provided opportunities to develop social competence through team-based activities and challenging experiences embedded in a needs-supportive environment, serving to support participants' psychological well-being and balanced development across the five Cs. Balanced development of the five Cs suggested adaptive developmental regulations were fostered during the OAE course, a process facilitated by participants developing the required psychosocial skills from attending Phase 1 of MST4Life and embracing the outdoor environment with a sense of optimism. There was also evidence of longer-term benefits, with participants reflecting improved well-being and resilience (indicators of mental health) and intrinsically driven intentions for positive change beyond the course.

A unique ecological asset of the OAE course was a needs-supportive climate; in particular, feelings of relatedness were a central theme in positive experiences. Previous research corroborates this finding, highlighting how fostering a sense of belonging in disadvantaged young people is associated with enjoyment and personal growth in outdoors-based programs (Bowen \& Neill, 2016; Bowers et al., 2019). However, building a sense of belonging can be difficult in shorter courses (e.g., 3 to 5 days) and in groups unfamiliar with the outdoors (Bowers et al., 2019). The present study provides a novel, theory-informed solution to this issue, indicating a needs supportive atmosphere (informed by SDT) can foster positive adultyouth and peer-peer relationships during a 3- to 4-day course. Integration of principles from SDT and relational developmental systems demonstrates the compatibility of these theories to inform contextual conditions and motivational climates that promote positive outcomes during OAE-based youth development courses (Sibthorp et al., 2007; Sproule et al., 2013).

Additionally, findings from the current study suggest a needs-supportive climate can promote psychological well-being and development of young people unfamiliar with the outdoors. 


\section{Promoting Personal Growth}

Aligning developmental and motivational theories is an important consideration for making outdoor courses more accessible for marginalized young people (Browne et al., 2019; Warren et al., 2014). Practitioners implementing OAE courses for young people with complex support needs should consider how participants' basic psychological needs are supported to maximize potential short- and longer-term benefits. Future research exploring the efficacy of multitheoretical and psychologically-informed approaches to OAE-based PYD programs would provide valuable applied and conceptual insights (Brink \& Wissing, 2012; MacKenzie et al., 2014).

Adaptive developmental regulations were also fostered through the participants' strengths. Embracing new experiences and challenges with a sense of optimism reflected how participants approached the OAE course with a growth mindset (O'Brien \& Lomas, 2017). A growth mindset typically reflects a perception that challenges are opportunities to learn (Elliot \& Dweck, 1998) and has been associated with feelings of resilience and self-efficacy in an outdoor personal development program-outcomes reflected in the present study (O'Brien \& Lomas, 2017). Optimism and resilience in young people experiencing homelessness have been correlated with life satisfaction (Rew et al., 2019); however, without intervention, this population often have negative outlooks on their futures (Kidd, 2007). Through Phase 1 of MST4Life, participants developed a growth mindset in preparation for the OAE course, exemplified in more positive self-perceptions, adaptive coping strategies, and intrinsically driven motivations (Cooley et al., 2019; Parry et al., 2021b; Quinton et al., 2021). The present study highlights the mutual benefits between appropriate psychological preparation before the OAE course and challenges presented during the OAE course, leading to personal growth, indicators of mental health, and changes in attitudes and intentions. This insight offers a theoretically informed and systematic approach to enabling diverse groups of young people to life-changing experiences during outdoor courses (Harper et al., 2019).

Mutually beneficial relations also appeared between participants having a sense of optimism and the OAE course being far removed from participants' everyday norms. In their home lives, young people experiencing homelessness can feel the burden of their circumstances through socially stigmatizing perceptions (Farrugia, 2011; Watson \& Cuervo, 2017). When understood through the lens of relational developmental systems, perceived social judgement and low socioeconomic status are barriers to adaptive developmental opportunities (Lerner \& Overton, 2008). OAE courses provide a unique opportunity for young people to experience respite from regular stressors and embrace personal development opportunities (Coates \& McKenzie-Mohr, 2010). More broadly, the notion of removing young people from stressful environments and into 


\section{Promoting Personal Growth}

physically and psychologically safe spaces that can nurture personal growth and mental health could be an effective strategy for services supporting youth with adverse childhood experiences (Lorenc et al., 2020). In the present study, the OAE course provided meaningful and powerful experiences that nurtured personal growth and laid the foundations for longer-term benefits.

Personal growth during the OAE course was understood through the five Cs of PYD (Lerner et al., 2005; Mercier et al., 2019). The most influential construct appeared to be social competence, reflected by participants' capacity to give and receive social support effectively. Young people experiencing homelessness often have developmental and psychosocial skill deficits, resulting in difficulties forming healthy relationships (Falci et al., 2011; Rokach, 2005). Studies into youth homelessness recognize the importance of young people's social well-being; however, the role of social competence has not been studied (Morton et al., 2020). In a group of at-risk adolescents, participants with greater social competence were more likely to experience educational success and reduced delinquency in early adulthood (Stepp et al., 2011). This would suggest that improving social competence could act as a protective factor against prevalent support needs in young people experiencing homelessness, including social exclusion and mental health issues (Homeless Link, 2018). Moreover, given the effectiveness of SDT-informed housing services to promote quality of life and perceptions of social support (Krabbenborg et al., 2017), social competence may enhance young people's capacity to engage with psychologically informed services (Cumming et al., 2017). As such, the youth homeless sector would benefit from PYD and OAE programs due to their propensity to foster social competence and, thus, enhance young people's capacity for positive engagement and personal growth.

\section{Strengths and Limitations}

During the 5-year data collection period, changes were made to the OAE course; most notably, it was extended from 3 to 4 days. In keeping with the community-based participatory approach of the MST4Life project, the course was extended based on findings from research action cycles and stakeholder consultations (Cumming et al., 2021). Reassuringly, recent fidelity research suggests strong adherence to delivery guidelines across different program cohorts (Tidmarsh et al., 2021). No discernible differences in data collected from cohorts who participated in the 3day or 4-day course would suggest the length of the OAE course did not appear to have a major influence on participants' experiences.

The present study provides novel evidence of how the OAE course contributes to the societal and economic benefits of the MST4Life program. For instance, a recent cost-benefit analysis 


\section{Promoting Personal Growth}

suggested MST4Life can reduce the number of young people who are not in education, employment or training by 30 percentage points compared to psychologically informed case management support alone (Jabbour \& Siu, 2019). Along with additional evaluations of MST4Life (Cooley et al., 2019; Quinton et al., 2021; Parry et al., 2021b), there is a compelling case for the OAE course having an influential role in supporting longer-term changes through improvements in indicators of mental health and changes in intentions and attitudes. As such, commissioners should consider the potential longer-term cost benefits of funding outdoorsbased youth development programs when working with young people experiencing homelessness and complex support needs. Additional research providing follow-up measures of social inclusion and health status are required to strengthen the case for OAE courses being a cost-effective approach to tackling social and health inequalities.

The current study applied a semi-structured diary room method for data collection (Cooley et al., 2014). One methodological strength of the diary room method was that it could be implemented through a participatory approach, helping to promote more inclusive engagement by overcoming barriers, such as learning difficulties and nerves (Conolly, 2008; Cumming et al., 2021). Flexible use of the method was necessary to uphold the broader community-based participatory principles of the MST4Life research project and support participants' sense of autonomy in the research process (Cumming et al., 2021). In community-based research, upholding core values of research equity should always be considered in balance with maintaining research protocols. In the current study, supporting participants to engage with data collection in ways that helped them feel comfortable and confident took precedence over adhering to strict methodological protocols. However, the resulting variations in the method's application may have influenced how or what experiences were expressed. For instance, with a peer or researcher asking the questions, experiences may be susceptible to social desirability effects. On the other hand, peer interviewing has been found to limit social desirability in hardto-reach populations (Benoit et al., 2005). Additionally, when participants requested the researcher's support during the diary room, it was usually because a good rapport had been established. A strong sense of rapport with participants, coupled with being trained in qualitative data collection, could have helped to minimize social desirability effects (Bergen \& Labonté, 2020). On the other hand, there is evidence to suggest that strong rapport between researchers and participants can lead to sensitive and personal experiences not being shared in one-to-one qualitative data collection methods (Latkin et al., 2016). 


\section{Promoting Personal Growth}

\section{Conclusion}

Findings presented in this study support the efficacy of the MST4Life's OAE course to consistently create adaptive developmental regulations that foster improvements in personal growth and longer-term benefits in a diverse sample of young people experiencing homelessness. Additionally, findings highlighted how preparing participants with psychosocial skills and qualities (e.g., social skills, optimism) in a preceding psychoeducational programme enabled them to experience personal growth and well-being benefits during the OAE course. Personal growth was understood through the five Cs of PYD, of which social competence appeared to be the most influential construct for promoting thriving experiences and a socially supportive environment.

The present study provides support for the implementation of OAE-based youth development programs with young people experiencing homelessness. However, given the novel nature of this study, further research is required. Valuable contributions would include mixed-method evaluations of personal growth (i.e., adopting a five Cs framework) and mental health (i.e., well-being and resilience), as well as comparison and follow-up studies to generate a clearer understanding of the longer-term implications. More broadly, with an increasing number of young people experiencing health disparities in the wake of COVID-19 (Young Minds, 2021), policymakers and commissioners should consider the cost-effectiveness benefits of outdoorsbased youth development programmes to promote longer-term improvements in health and well-being.

\section{Author Note}

Benjamin John Parry is now a postdoctoral fellow at Clemson University.

\section{References}

Barbour, R. S. (2001, May 5). Checklists for improving rigour in qualitative research: A case of the tail wagging the dog? British Medical Journal. BMJ Publishing Group. (https://doi.org/10.1136/bmj.322.7294.1115)

Benoit, C., Jansson, M., Millar, A., \& Phillips, R. (2005). Community-academic research on hard-to-reach populations: Benefits and challenges. Qualitative Health Research, 15, 263-282.

Bergen, N., \& Labonté, R. (2020). "Everything is perfect, and we have no problems": Detecting and limiting social desirability bias in qualitative research. Qualitative Health Research, 30(5), 783792. (https://doi.org/10.1177/1049732319889354) 
Journal of Youth Development | http://jyd.pitt.edu/ | Vol. 16 Issue 5 DOI 10.5195/jyd.2021.1061

Promoting Personal Growth

Berry, T., Brown, K. M., Carr, W., Kemmis, S., Elliott, R., Fischer, C., Rennie, D., Frieden, S., Guba, E. G., Lincoln, Y. S., Haraway, D., Heron, J., hooks, b., Lather, P., LeCompte, M. D., McLaughlin, D., Merchant, C., Palmer, P. J., Reason, P. . . Zeller, N. (2002). Emerging criteria for quality in qualitative and interpretive research. In In N. K. Denzin \& Y. S. Lincoln (Eds.), The qualitative inquiry reader (pp. 326-345). Sage Publications. (https://doi.org/10.4135/9781412986267)

Bowen, D. J., \& Neill, J. T. (2016). Effects of the PCYC Catalyst outdoor adventure intervention program on youths' life skills, mental health, and delinquent behaviour. International Journal of Adolescence and Youth, 21(1), 34-55. (https://doi.org/10.1080/02673843.2015.1027716)

Bowers, E. P., Larson, L. R., \& Sandoval, A. M. (2019). Urban youth perspectives on the benefits and challenges of outdoor adventure camp. Journal of Youth Development, 14(4), 122-143. (https://doi.org/10.5195/JYD.2019.809)

Bowers, E. P., Larson, L. R., \& Parry, B. J. (2021). Nature as an ecological asset for positive youth development: Empirical evidence from rural communities [manuscript under review].

Brandtstädter, J. (2006). Action perspectives on human development. In W. Damon (Series Ed.) \& R. M. Lerner (Vol. Ed.), Handbook of Child Psychology: Vol. 1. Theoretical models of human development (6 $6^{\text {th }}$ ed., pp. 516-568). John Wiley \& Sons.

(https://doi.org/10.1002/9780470147658.chpsy0110)

Braun, V., \& Clarke, V. (2019). Reflecting on reflexive thematic analysis. Qualitative Research in Sport, Exercise and Health, 11(4), 589-597. (https://doi.org/10.1080/2159676X.2019.1628806)

Braun, V., \& Clarke, V. (2006). Using thematic analysis in psychology. Qualitative Research in Psychology, 3(2), 77-101. (https://doi.org/10.1191/1478088706qp063oa)

Brink, A. J. W., \& Wissing, M. P. (2012, July 1). A model for a positive youth development intervention. Journal of Child and Adolescent Mental Health. (https://doi.org/10.2989/17280583.2012.673491)

Browne, L. P., Gillard, A., \& Garst, B. A. (2019). Camp as an institution of socialization: past, present, and future. Journal of Experiential Education, 42(1), 51-64. (https://doi.org/10.1177/1053825918820369)

Coates, J., \& McKenzie-Mohr, S. (2010). Out of the frying pan, into the fire: Trauma in the lives of homeless youth prior to and during homelessness. Journal of Sociology and Social Welfare, $37(4), 65-96$.

Conolly, A. (2008). Challenges of generating qualitative data with socially excluded young people. International Journal of Social Research Methodology, 11(3), 201-214. (https://doi.org/10.1080/13645570701401446

Cooley, S. J., Holland, M. J. G., Cumming, J., Novakovic, E. G., \& Burns, V. E. (2014). Introducing the use of a semi-structured video diary room to investigate students' learning experiences during an 
Journal of Youth Development | http://jyd.pitt.edu/ | Vol. 16 Issue 5 DOI 10.5195/jyd.2021.1061

\section{Promoting Personal Growth}

outdoor adventure education groupwork skills course. Higher Education, 671), 105-121. (https://doi.org/10.1007/s10734-013-9645-5)

Cooley, S. J., Quinton, M. L., Holland, M. J. G., Parry B. J., Cumming J. (2019). The experiences of homeless youth when using strengths profiling to identify their character strengths. Frontiers in Psychology, 10 (September), 1-26. (https://doi.org/10.3389/fpsyg.2019.02036)

Cumming, J., Holland, M. J. G., Clarke, F., Parry, B. J., Quinton, M. L., \& Cooley, S. J., (2021). Improving outcomes in homeless young people: A feasibility study of the My Strengths Training for Life ${ }^{T M}$ (MST4Life ${ }^{T M}$ ) Programme [manuscript in preparation]. School of Sport, Exercise and Rehabilitation Sciences, University of Birmingham

Cumming, J., Skeate, A., Giles, A. (2017). Case Study 130: St Basils psychologically informed environments - Meeting the emotional and psychological needs of young homeless people. Housing Learning and Improvement.

Damon, W. (2004). What is positive youth development? Annals of the American Academy of Political and Social Science, 591(January), 13-24. (https://doi.org/10.1177/0002716203260092)

Eccles, J., \& Gootman, J. A., (Eds.). (2002). Community programs to promote youth development. National Academies Press. (https://doi.org/10.17226/10022)

Edidin, J. P., Ganim, Z., Hunter, S. J., \& Karnik, N. S. (2012). The mental and physical health of homeless youth: A literature review. Child Psychiatry and Human Development, 43(3), 354-375. (https://doi.org/10.1007/s10578-011-0270-1)

Elliott, E. S., \& Dweck, C. S. (1988). Goals: An approach to motivation and achievement. Journal of Personality and Social Psychology, 54(1), 5-12. (https://doi.org/10.1037/0022-3514.54.1.5)

Falci, C. D., Whitbeck, L. B., Hoyt, D. R., \& Rose, T. (2011). Predictors of change in self-reported social networks among homeless young people. Journal of Research on Adolescence, 21(4), 827-841. (https://doi.org/10.1111/j.1532-7795.2011.00741.x)

Farrugia, D. (2011). The symbolic burden of homelessness: Towards a theory of youth homelessness as embodied subjectivity. Journal of Sociology, 47(1), 71-87.

(https://doi.org/10.1177/1440783310380989)

Feilzer, M. Y. (2010). Doing mixed methods research pragmatically: Implications for the rediscovery of pragmatism as a research paradigmv. Journal of Mixed Methods Research, 4(1), 6-16. (https://doi.org/10.1177/1558689809349691)

Forrest-Bank, S. S., Nicotera, N., Anthony, E. K., \& Jenson, J. M. (2015). Finding their way: Perceptions of risk, resilience, and positive youth development among adolescents and young adults from public housing neighborhoods. Children and Youth Services Review, 55, 147-158. (https://doi.org/10.1016/j.childyouth.2015.05.015) 
Journal of Youth Development | http://jyd.pitt.edu/ | Vol. 16 Issue 5 DOI 10.5195/jyd.2021.1061

Promoting Personal Growth

Harper, N. J., Mott, A. J., \& Obee, P. (2019). Client perspectives on wilderness therapy as a component of adolescent residential treatment for problematic substance use and mental health issues. Children and Youth Services Review, 105(May), 104450. (https://doi.org/10.1016/j.childyouth.2019.104450)

Hattie, J., Marsh, H. W., Neill, J. T., \& Richards, G. E. (1997). Adventure education and Outward Bound: Out-of-class experiences that make a lasting difference. Review of Educational Research, 67(1), 43-87. https://doi.org/10.3102/00346543067001043

Holsen, I., Geldhof, J., Larsen, T., \& Aardal, E. (2017). The five Cs of positive youth development in Norway: Assessment and associations with positive and negative outcomes. International Journal of Behavioral Development, 41(5), 559-569. (https://doi.org/10.1177/0165025416645668)

Homeless Link Research Team. (2018). Young \& homeless 2018. (https://doi.org/10.3171/2016.4.JNS152896)

Jabbour, L., Siu, J., (2019). Economic evaluation of the psychologically informed environments: Costbenefit analysis of Boost and MST4Life ${ }^{\mathrm{TM}}$ programmes at St Basils. (https://8fe30357-2dc5-4c2cb70d-5b8e78fc2795.filesusr.com/ugd/f51c2c_0b5ec76cd5ac4de58ae4c5d66da9f401.pdf)

Kidd, S. A. (2007). Youth homelessness and social stigma. Journal of Youth and Adolescence, 36(3), 291299. (https://doi.org/10.1007/s10964-006-9100-3)

Kirkpatrick, D. (1994). Evaluating training programs: The four levels. Berrett-Koehler.

Krabbenborg, M. A. M., Boersma, S. N., van der Veld, W. M., Vollebergh, W. A. M., \& Wolf, J. R. L. M. (2017). Self-determination in relation to quality of life in homeless young adults: Direct and indirect effects through psychological distress and social support. Journal of Positive Psychology, 12(2), 130-140. (https://doi.org/10.1080/17439760.2016.1163404)

Latkin, C. A., Mai, N. V., Ha, T. V., Sripaipan, T., Zelaya, C., Le Minh, N., Morales, G., \& Go, V. F. (2016). Social desirability response bias and other factors that may influence self-reports of substance use and hiv risk behaviors: A qualitative study of drug users in vietnam. AIDS education and prevention: official publication of the International Society for AIDS Education, 28(5), 417-425. (https://doi.org/10.1521/aeap.2016.28.5.417)

Lerner, R. M., Dowling, E. M., \& Anderson, P. M. (2003). Positive youth development: Thriving as the basis of personhood and civil society. Applied Developmental Science, $7(3), 172-180$. (https://doi.org/10.1207/S1532480XADS0703_8)

Lerner, R. M., Lerner, J. V., Almerigi, J. B., Theokas, C., Phelps, E., Gestsdottir, S., Naudeau, S., Jelicic, H., Alberts, A., Ma, L., Smith, L. M., Boek, D. L., Richman-Raphael, D., Simpson, I., DiDenti Christiansen, E., \& von Eye, A. (2005). Positive youth development, participation in community youth development programs, and community contributions of fifth-grade adolescents: Findings 
Journal of Youth Development | http://jyd.pitt.edu/ | Vol. 16 Issue 5 DOI 10.5195/jyd.2021.1061

Promoting Personal Growth

from the first wave of the 4-H study of positive youth development. Journal of Early Adolescence, 25(1), 17-71. (https://doi.org/10.1177/0272431604272461 )

Lerner, R. M., Lerner, J. V., Lewin-Bizan, S., Bowers, E. P., Boyd, M. J., Mueller, M. K., Schmid, C., \& Napolitano, C. M. (2011). Positive youth development: Processes, programs, and

problematics. Journal of Youth Development, 6(3), 38-62. (https://doi.org/10.5195/jyd.2011.174)

Lerner, R. M., \& Overton, W. F. (2008). Exemplifying the integrations of the relational developmental system: Synthesizing theory, research, and application to promote positive development and social justice. Journal of Adolescent Research, 23(3), 245-255.

(https://doi.org/10.1177/0743558408314385)

Levitt, H. M., Motulsky, S. L., Wertz, F. J., Morrow, S. L., \& Ponterotto, J. G. (2017). Recommendations for designing and reviewing qualitative research in psychology: Promoting methodological integrity. Qualitative Psychology, 4(1), 2-22. (https://doi.org/10.1037/qup0000082)

Lincoln, Y. S., \& Denzin, N. K. (2011). Emerging criteria for quality in qualitative and interpretive research. In N. K. Denzin \& Y. S. Lincoln (Eds.), The qualitative inquiry reader (pp. 326-345). Sage Publications.

Lorenc, T., Lester, S., Sutcliffe, K., Stansfield, C., \& Thomas, J. (2020). Interventions to support people exposed to adverse childhood experiences: Systematic review of systematic reviews. BMC Public Health, 2a1). (https://doi.org/10.1186/s12889-020-08789-0)

Mackenzie, S., Son, J. S., \& Hollenhorst, S. (2014). Unifying psychology and experiential education: toward an integrated understanding of why it works. Journal of Experiential Education, 371), 7588. (https://doi.org/10.1177/1053825913518894)

Mercier, J., Powell, C., Langdon-Pole, G., Finau, D., Hicks, K., Bourchier, L., \& Hampton, J. (2019). The five Cs of positive youth development in an Aotearoa/New Zealand program context. Journal of Youth Development, 14(4), 36-58. (https://doi.org/10.5195/JYD.2019.774)

Mertens, D. M. (2007). Transformative Paradigm: Mixed Methods and Social Justice. Journal of Mixed Methods Research, 1(3), 212-225. (https://doi.org/10.1177/1558689807302811)

Morgan, D. L. (2014). Pragmatism as a paradigm for social research. Qualitative Inquiry, 20(8), 10451053. (https://doi.org/10.1177/1077800413513733)

Morton, M. H., Dworsky, A., Matjasko, J. L., Curry, S. R., Schlueter, D., Chávez, R., \& Farrell, A. F. (2018). Prevalence and correlates of youth homelessness in the United States. Journal of Adolescent Health, 62(1), 14-21. (https://doi.org/10.1016/j.jadohealth.2017.10.006)

Morton, M. H., Kugley, S., Epstein, R., \& Farrell, A. (2020). Interventions for youth homelessness: A systematic review of effectiveness studies. Children and Youth Services Review, 116(May). (https://doi.org/10.1016/j.childyouth.2020.105096) 
Journal of Youth Development | http://jyd.pitt.edu/ | Vol. 16 Issue 5 DOI 10.5195/jyd.2021.1061

Promoting Personal Growth

Mygind, L., Kjeldsted, E., Hartmeyer, R., Mygind, E., Bølling, M., \& Bentsen, P. (2019). Mental, physical and social health benefits of immersive nature-experience for children and adolescents: A systematic review and quality assessment of the evidence. Health and Place, 58(October 2018), 102136. (https://doi.org/10.1016/j.healthplace.2019.05.014)

Norton, C. L., \& Watt, T. T. (2014). Exploring the impact of a wilderness-based positive youth development program for urban youth. Journal of Experiential Education, 374), 335-350. (https://doi.org/10.1177/1053825913503113)

Nowell, L. S., Norris, J. M., White, D. E., \& Moules, N. J. (2017). Thematic analysis: Striving to meet the trustworthiness criteria. International Journal of Qualitative Methods, 16(1). (https://doi.org/10.1177/1609406917733847)

O'Brien, K., \& Lomas, T. (2017). Developing a growth mindset through outdoor personal development: Can an intervention underpinned by psychology increase the impact of an outdoor learning course for young people? Journal of Adventure Education and Outdoor Learning, 17(2), 133-147. (https://doi.org/10.1080/14729679.2016.1232199)

Parry, B. J., Thompson. J. L., Holland, M. J. G., Cooley, S. J., Quinton, M. L., \& Cumming, J. (2021a). Health outcomes of physical activity-based positive youth development for disadvantaged young people: A systematic review [manuscript in preparation]. School of Sport, Exercise and Rehabilitation Sciences, University of Birmingham, UK.

Parry, B. J., Thompson. J. L., Holland, M. J. G., Quinton, M. L., \& Cumming, J. (2021b). Improving outcomes in young people experiencing homelessness with My Strengths Training for Life ${ }^{\mathrm{TM}}$ (MST4Life ${ }^{\mathrm{TM}}$ ): A qualitative realist evaluation. Children and Youth Services Review. 121, 105793 (https://doi.org/10.1016/j.childyouth.2020.105793)

Quinton, M. L., Clarke, F. J., Parry, B. J., \& Cumming, J. (2021). An evaluation of My Strengths Training for Life ${ }^{\mathrm{TM}}$ for improving resilience and well-being of young people experiencing homelessness. Journal of Community Psychology, 1-19. (https://doi.org/10.1002/jcop.22517)

Rew, L., Slesnick, N., Johnson, K., Aguilar, R., \& Cengiz, A. (2019). Positive attributes and life satisfaction in homeless youth. Children and Youth Services Review, 100(February), 1-8. (https://doi.org/10.1016/j.childyouth.2019.02.021)

Rice, E., Kurzban, S., \& Ray, D. (2012). Homeless but connected: the role of heterogeneous social network ties and social networking technology in the mental health outcomes of street-living adolescents. Community Mental Health Journal, 48(6), 692-698. (https://doi.org/10.1007/s10597-011-9462-1)

Rokach, A. (2005). The causes of loneliness in homeless youth. Journal of Psychology: Interdisciplinary and Applied, 139(5), 469-480. (https://doi.org/10.3200/JRLP.139.5.469-480) 
Journal of Youth Development | http://jyd.pitt.edu/ | Vol. 16 Issue 5 DOI 10.5195/jyd.2021.1061

Promoting Personal Growth

Romm, N. (2014). Exploration of transformative paradigm with pragmatic twist to contribute to educational change. International Journal on New Trends in Education and Their Implications, 5(2), 12.

Roth, J. L., \& Brooks-Gunn, J. (2003). What is a youth development program? Identifying defining principles. In R. M. Lerner, F. Jacobs, \& D. Wertlieb (Eds.), Handbook of applied developmental science: Promoting positive child, adolescent, and family development through research, policies, and programs. Enhancing the life chances of youth and families (Vol. 2, pp. 197-224). SAGE.

Russell, C. V., \& Bisson, C. (2003). Teaching group formation activities, group formation tools and group process tools. In S. Wurdinger and J. Steffen (Eds.), Developing challenge course programs for schools (pp. 103-138). Kendall Hunt.

Ryan, R. M., \& Deci, E. L. (2000). Self-determination theory and the facilitation of intrinsic motivation, social development, and wellbeing. The American Psychologist, 55, 68-78. (https://doi.org/doi:10.1037//0003-066x.55.1.68)

Sibthorp, J., \& Morgan, C. (2011). Adventure-based programming: exemplary youth development practice. New Directions for Youth Development, 2011(130), 105-119. (https://doi.org/10.1002/yd.400)

Sibthorp, J., Paisley, K., \& Gookin, J. (2007). Exploring participant development through adventure-based programming: a model from the National Outdoor Leadership School. Leisure Sciences, 29(1), 118. (https://doi.org/doi:10.1080/01490400600851346)

Smith, B., \& McGannon, K. R. (2018). Developing rigor in qualitative research: problems and opportunities within sport and exercise psychology. International Review of Sport and Exercise Psychology, 11(1), 101-121. (https://doi.org/10.1080/1750984X.2017.1317357)

Sproule, J., Martindale, R., Wang, J., Allison, P., Nash, C., \& Gray, S. (2013). Investigating the experience of outdoor and adventurous project work in an educational setting using a self-determination framework. European Physical Education Review, 19(3), 315-328. (https://doi.org/10.1177/1356336X13495629)

Stepp, S. D., Pardini, D. A., Loeber, R., \& Morris, N. A. (2011). The relation between adolescent social competence and young adult delinquency and educational attainment among at-risk youth: The mediating role of peer delinquency. Canadian Journal of Psychiatry (Revue Canadienne de Psychiatrie), 56(8), 457-465. (https://doi.org/10.1177/070674371105600803)

Tidmarsh, G., Whiting, R. J., Thompson, J. L., \& Cumming, J. (2021). Assessing the fidelity of delivery style of a mental skills training programme for young people experiencing homelessness [manuscript submitted for publication]. School of Sport, Exercise and Rehabilitation Sciences, University of Birmingham, UK. 
Journal of Youth Development | http://jyd.pitt.edu/ | Vol. 16 Issue 5 DOI 10.5195/jyd.2021.1061 Promoting Personal Growth

Tillmann, S., Tobin, D., Avison, W., \& Gilliland, J. (2018, June 27). Mental health benefits of interactions with nature in children and teenagers: A systematic review. Journal of Epidemiology and Community Health. BMJ Publishing Group. (https://doi.org/10.1136/jech-2018-210436)

Tracy, S. J. (2010). Qualitative quality: Eight a"big-tent" criteria for excellent qualitative research. Qualitative Inquiry, 16(10), 837-851. https://doi.org/10.1177/1077800410383121

Warren, K., Roberts, N. S., Breunig, M., \& Alvarez, M. A. G. (2014). Social justice in outdoor experiential education: A state of knowledge review. Journal of Experiential Education, 37, 1-15. (https://doi.org/doi:10.1177/1053825913518898)

Watson, J., \& Cuervo, H. (2017). Youth homelessness: A social justice approach. Journal of Sociology, 53(2), 461-475. (https://doi.org/10.1177/1440783317705204)

Young Minds. (2021). Coronavirus: Impact on young people with mental health needs Survey 4: February 2021. (https://youngminds.org.uk/media/4350/coronavirus-report-winter.pdf) 


\section{Promoting Personal Growth}

\section{Appendix \\ Positionality Statement}

In the present study, reflexive thematic analysis was applied when constructing themes from the experiences of participants taking part in an outdoor adventure education course (OAE; Braun \& Clarke, 2019). As part of this analytical approach, the researcher is required to disclaim their positionality within the research and how this influenced their interpretation of the data (Braun \& Clarke, 2019). This supplementary material aims to fulfil this integral process to the reflective thematic analysis conducted in the main text.

As lead researcher, I conducted the main data analysis, consulting with the wider research in critical discussions to reflect upon, refine, and reconsider themes in an iterative process (Smith \& McGannon, 2017). However, I was not present in all cohorts of the OAE course and therefore, did not have an active role in programme delivery and data collection with all participants (approximately one-third of the sample). In these cases, I consulted researchers that were present during the OAE course to build a richer understanding of the participants, contextualise the data, and clarify any points of uncertainty (e.g., if a particular moment during the course was referenced during data collection).

For data collection from the rest of the sample, I held the position of research assistant (e.g., supporting programme delivery and data collection duties) and programme facilitator (e.g., lead role in programme delivery and data collection duties). In preparation for both roles, I received training and guidance to develop my understanding of working with young people experiencing homelessness. Firstly, I received the housing organisations bespoke Psychologically Informed Environments training, which aimed to develop an awareness of the impact of childhood trauma and provide psychological tools to respond to young people's complex support needs in an adaptive way (Cumming et al., 2017). In addition, I received informal training from fellow researchers and facilitators of the programme on how to support young people's basic psychological needs during programme delivery. Moreover, I received guidance from fellow researchers and housing staff to aid my applied knowledge, as well as structured reflective practice with a clinical psychologist from the housing service. As a result of training, guidance, and hands-on experience, I developed theory-informed and applied conversational techniques to build healthy, positive relationships with young people. Moreover, I believe my genuine passion for working with young people allowed me to have authentic discussions, pathing the way to building genuine rapport and having an invested interest in their development. 


\section{Promoting Personal Growth}

Having a hands-on role delivering Phase 1 of the programme, I had typically got to know participants well by the time of the OAE course. There was a common trend of participants being more willing to engage in the diary room during the OAE course compared to Phase 1 . In part, I believe engagement was facilitated by growth in confidence from Phase 1 of the programme, with more young people being willing to complete a diary room on their own. There were still participants who preferred to have a researcher ask the questions (typically myself as I took a lead role in data collection during the course); however, these were participants who often had not engaged with the dairy room method until this point. In diary room entries where I asked the questions, participants seemed relaxed to engage with myself and, in my opinion, answered the questions honestly. I believe the rapport I had established with participants played an important role in reducing the possible effects of social desirability (Bergen \& Labonté, 2020). Whilst my presence may have influenced the responses given (and, in some capacity likely did), it also helped young people feel more comfortable to engage in the data collection process, which, ultimately, contributed to building a more enriched understanding of how the sample, as a whole, experienced the OAE course.

Young people were also more willing to engage in discussions in an informal capacity too. For instance, during the mountain walk, myself, other researchers, St Basils staff and the instructors all reflected on young people opening up to a range of things going on in their lives in one-toone conversations. Informal conversations away from data collection meant I started to get to know the participants on a deeper level, which made me feel even more compelled to be mindful to convey their narrative when constructing my interpretation of their words. Ultimately, what I learned from my experiences was that the OAE course offered much greater value than just skill development. During the course young people went on a journey, both geographically and personally, and whilst each journey was different, I felt there was a common theme of personal growth across the cohorts.

In conclusion, I concede that my experiences with participants and involvement in the My Strengths Training for Life ${ }^{\mathrm{TM}}$ programme shaped my interpretation of the data in the present study. However, it was also these experiences and hands-on role that allowed me to build a deeper understanding of participants' journeys. As such, my invested interest in the participants and social cause of the research served to reinforce the importance of doing justice to the rich, complex, and nuanced narratives of each and every participant. 
Journal of Youth Development | http://jyd.pitt.edu/ | Vol. 16 Issue 5 DOI 10.5195/jyd.2021.1061

Promoting Personal Growth

\section{References}

Barbour, R. S. (2001, May 5). Checklists for improving rigour in qualitative research: A case of the tail wagging the dog? British Medical Journal. BMJ Publishing Group. (https://doi.org/10.1136/bmj.322.7294.1115)

Benoit, C., Jansson, M., Millar, A., \& Phillips, R. (2005). Community-academic research on hard-to-reach populations: Benefits and challenges. Qualitative Health Research, 15, 263-282.

Bergen, N., \& Labonté, R. (2020). "Everything is perfect, and we have no problems": Detecting and limiting social desirability bias in qualitative research. Qualitative Health Research, 30(5), 783792. (https://doi.org/10.1177/1049732319889354)

Berry, T., Brown, K. M., Carr, W., Kemmis, S., Elliott, R., Fischer, C., Rennie, D., Frieden, S., Guba, E. G., Lincoln, Y. S., Haraway, D., Heron, J., hooks, b., Lather, P., LeCompte, M. D., McLaughlin, D., Merchant, C., Palmer, P. J., Reason, P. . . Zeller, N. (2002). Emerging criteria for quality in qualitative and interpretive research. In In N. K. Denzin \& Y. S. Lincoln (Eds.), The qualitative inquiry reader (pp. 326-345). Sage Publications. (https://doi.org/10.4135/9781412986267)

Bowen, D. J., \& Neill, J. T. (2016). Effects of the PCYC Catalyst outdoor adventure intervention program on youths' life skills, mental health, and delinquent behaviour. International Journal of Adolescence and Youth, 21(1), 34-55. (https://doi.org/10.1080/02673843.2015.1027716)

Bowers, E. P., Larson, L. R., \& Sandoval, A. M. (2019). Urban youth perspectives on the benefits and challenges of outdoor adventure camp. Journal of Youth Development, 14(4), 122-143. (https://doi.org/10.5195/JYD.2019.809)

Bowers, E. P., Larson, L. R., \& Parry, B. J. (2021). Nature as an ecological asset for positive youth development: Empirical evidence from rural communities [manuscript under review].

Brandtstädter, J. (2006). Action perspectives on human development. In W. Damon (Series Ed.) \& R. M. Lerner (Vol. Ed.), Handbook of Child Psychology: Vol. 1. Theoretical models of human development (6 $6^{\text {th }}$ ed., pp. 516-568). John Wiley \& Sons. (https://doi.org/10.1002/9780470147658.chpsy0110)

Braun, V., \& Clarke, V. (2019). Reflecting on reflexive thematic analysis. Qualitative Research in Sport, Exercise and Health, 11(4), 589-597. (https://doi.org/10.1080/2159676X.2019.1628806)

Braun, V., \& Clarke, V. (2006). Using thematic analysis in psychology. Qualitative Research in Psychology, 3(2), 77-101. (https://doi.org/10.1191/1478088706qp063oa)

Brink, A. J. W., \& Wissing, M. P. (2012, July 1). A model for a positive youth development intervention. Journal of Child and Adolescent Mental Health. (https://doi.org/10.2989/17280583.2012.673491) 
Journal of Youth Development | http://jyd.pitt.edu/ | Vol. 16 Issue 5 DOI 10.5195/jyd.2021.1061

Promoting Personal Growth

Browne, L. P., Gillard, A., \& Garst, B. A. (2019). Camp as an institution of socialization: past, present, and future. Journal of Experiential Education, 42(1), 51-64.

(https://doi.org/10.1177/1053825918820369)

Coates, J., \& McKenzie-Mohr, S. (2010). Out of the frying pan, into the fire: Trauma in the lives of homeless youth prior to and during homelessness. Journal of Sociology and Social Welfare, $3 \pi 4), 65-96$.

Conolly, A. (2008). Challenges of generating qualitative data with socially excluded young people. International Journal of Social Research Methodology, 11(3), 201-214. (https://doi.org/10.1080/13645570701401446

Cooley, S. J., Holland, M. J. G., Cumming, J., Novakovic, E. G., \& Burns, V. E. (2014). Introducing the use of a semi-structured video diary room to investigate students' learning experiences during an outdoor adventure education groupwork skills course. Higher Education, 6ス1), 105-121. (https://doi.org/10.1007/s10734-013-9645-5)

Cooley, S. J., Quinton, M. L., Holland, M. J. G., Parry B. J., Cumming J. (2019). The experiences of homeless youth when using strengths profiling to identify their character strengths. Frontiers in Psychology, 10 (September), 1-26. (https://doi.org/10.3389/fpsyg.2019.02036)

Cumming, J., Holland, M. J. G., Clarke, F., Parry, B. J., Quinton, M. L., \& Cooley, S. J., (2021). Improving outcomes in homeless young people: A feasibility study of the My Strengths Training for Life ${ }^{T M}$ (MST4Life ${ }^{T M}$ ) Programme [manuscript in preparation]. School of Sport, Exercise and Rehabilitation Sciences, University of Birmingham

Cumming, J., Skeate, A., Giles, A. (2017). Case Study 130: St Basils psychologically informed environments - Meeting the emotional and psychological needs of young homeless people. Housing Learning and Improvement.

Damon, W. (2004). What is positive youth development? Annals of the American Academy of Political and Social Science, 591(January), 13-24. (https://doi.org/10.1177/0002716203260092)

Eccles, J., \& Gootman, J. A., (Eds.). (2002). Community programs to promote youth development. National Academies Press. (https://doi.org/10.17226/10022)

Edidin, J. P., Ganim, Z., Hunter, S. J., \& Karnik, N. S. (2012). The mental and physical health of homeless youth: A literature review. Child Psychiatry and Human Development, 43(3), 354-375. (https://doi.org/10.1007/s10578-011-0270-1)

Elliott, E. S., \& Dweck, C. S. (1988). Goals: An approach to motivation and achievement. Journal of Personality and Social Psychology, 54(1), 5-12. (https://doi.org/10.1037/0022-3514.54.1.5)

Falci, C. D., Whitbeck, L. B., Hoyt, D. R., \& Rose, T. (2011). Predictors of change in self-reported social networks among homeless young people. Journal of Research on Adolescence, 21(4), 827-841. (https://doi.org/10.1111/j.1532-7795.2011.00741.x) 
Journal of Youth Development | http://jyd.pitt.edu/ | Vol. 16 Issue 5 DOI 10.5195/jyd.2021.1061

Promoting Personal Growth

Farrugia, D. (2011). The symbolic burden of homelessness: Towards a theory of youth homelessness as embodied subjectivity. Journal of Sociology, 47(1), 71-87.

(https://doi.org/10.1177/1440783310380989)

Feilzer, M. Y. (2010). Doing mixed methods research pragmatically: Implications for the rediscovery of pragmatism as a research paradigmv. Journal of Mixed Methods Research, 4(1), 6-16. (https://doi.org/10.1177/1558689809349691)

Forrest-Bank, S. S., Nicotera, N., Anthony, E. K., \& Jenson, J. M. (2015). Finding their way: Perceptions of risk, resilience, and positive youth development among adolescents and young adults from public housing neighborhoods. Children and Youth Services Review, 55, 147-158.

(https://doi.org/10.1016/j.childyouth.2015.05.015)

Harper, N. J., Mott, A. J., \& Obee, P. (2019). Client perspectives on wilderness therapy as a component of adolescent residential treatment for problematic substance use and mental health issues.

Children and Youth Services Review, 105(May), 104450.

(https://doi.org/10.1016/j.childyouth.2019.104450)

Hattie, J., Marsh, H. W., Neill, J. T., \& Richards, G. E. (1997). Adventure education and Outward Bound: Out-of-class experiences that make a lasting difference. Review of Educational Research, 671), 43-87. https://doi.org/10.3102/00346543067001043

olsen, I., Geldhof, J., Larsen, T., \& Aardal, E. (2017). The five Cs of positive youth development in Norway: Assessment and associations with positive and negative outcomes. International Journal of Behavioral Development, 41(5), 559-569. (https://doi.org/10.1177/0165025416645668)

Homeless Link Research Team. (2018). Young \& homeless 2018.

(https://doi.org/10.3171/2016.4.JNS152896)

Jabbour, L., Siu, J., (2019). Economic evaluation of the psychologically informed environments: Costbenefit analysis of Boost and MST4Life ${ }^{T M}$ programmes at St Basils. (https://8fe30357-2dc5-4c2cb70d-5b8e78fc2795.filesusr.com/ugd/f51c2c_0b5ec76cd5ac4de58ae4c5d66da9f401.pdf)

Kidd, S. A. (2007). Youth homelessness and social stigma. Journal of Youth and Adolescence, 36(3), 291299. (https://doi.org/10.1007/s10964-006-9100-3)

Kirkpatrick, D. (1994). Evaluating training programs: The four levels. Berrett-Koehler.

Krabbenborg, M. A. M., Boersma, S. N., van der Veld, W. M., Vollebergh, W. A. M., \& Wolf, J. R. L. M. (2017). Self-determination in relation to quality of life in homeless young adults: Direct and indirect effects through psychological distress and social support. Journal of Positive Psychology, 12(2), 130-140. (https://doi.org/10.1080/17439760.2016.1163404)

Latkin, C. A., Mai, N. V., Ha, T. V., Sripaipan, T., Zelaya, C., Le Minh, N., Morales, G., \& Go, V. F. (2016). Social desirability response bias and other factors that may influence self-reports of substance use and hiv risk behaviors: A qualitative study of drug users in vietnam. AIDS education and 
Journal of Youth Development | http://jyd.pitt.edu/ | Vol. 16 Issue 5 DOI 10.5195/jyd.2021.1061 Promoting Personal Growth

prevention: official publication of the International Society for AIDS Education, 28(5), 417-425. (https://doi.org/10.1521/aeap.2016.28.5.417)

Lerner, R. M., Dowling, E. M., \& Anderson, P. M. (2003). Positive youth development: Thriving as the basis of personhood and civil society. Applied Developmental Science, 73), 172-180. (https://doi.org/10.1207/S1532480XADS0703_8)

Lerner, R. M., Lerner, J. V., Almerigi, J. B., Theokas, C., Phelps, E., Gestsdottir, S., Naudeau, S., Jelicic, H., Alberts, A., Ma, L., Smith, L. M., Boek, D. L., Richman-Raphael, D., Simpson, I., DiDenti Christiansen, E., \& von Eye, A. (2005). Positive youth development, participation in community youth development programs, and community contributions of fifth-grade adolescents: Findings from the first wave of the 4-H study of positive youth development. Journal of Early Adolescence, 25(1), 17-71. (https://doi.org/10.1177/0272431604272461 )

Lerner, R. M., Lerner, J. V., Lewin-Bizan, S., Bowers, E. P., Boyd, M. J., Mueller, M. K., Schmid, C., \& Napolitano, C. M. (2011). Positive youth development: Processes, programs, and problematics. Journal of Youth Development, 6(3), 38-62. (https://doi.org/10.5195/jyd.2011.174 ) Lerner, R. M., \& Overton, W. F. (2008). Exemplifying the integrations of the relational developmental system: Synthesizing theory, research, and application to promote positive development and social justice. Journal of Adolescent Research, 23(3), 245-255.

(https://doi.org/10.1177/0743558408314385)

Levitt, H. M., Motulsky, S. L., Wertz, F. J., Morrow, S. L., \& Ponterotto, J. G. (2017). Recommendations for designing and reviewing qualitative research in psychology: Promoting methodological integrity. Qualitative Psychology, 4(1), 2-22. (https://doi.org/10.1037/qup0000082)

Lincoln, Y. S., \& Denzin, N. K. (2011). Emerging criteria for quality in qualitative and interpretive research. In N. K. Denzin \& Y. S. Lincoln (Eds.), The qualitative inquiry reader (pp. 326-345). Sage Publications.

Lorenc, T., Lester, S., Sutcliffe, K., Stansfield, C., \& Thomas, J. (2020). Interventions to support people exposed to adverse childhood experiences: Systematic review of systematic reviews. BMC Public Health, 2a1). (https://doi.org/10.1186/s12889-020-08789-0)

Mackenzie, S., Son, J. S., \& Hollenhorst, S. (2014). Unifying psychology and experiential education: toward an integrated understanding of why it works. Journal of Experiential Education, 371), 7588. (https://doi.org/10.1177/1053825913518894)

Mercier, J., Powell, C., Langdon-Pole, G., Finau, D., Hicks, K., Bourchier, L., \& Hampton, J. (2019). The five Cs of positive youth development in an Aotearoa/New Zealand program context. Journal of Youth Development, 14(4), 36-58. (https://doi.org/10.5195/JYD.2019.774) 
Journal of Youth Development | http://jyd.pitt.edu/ | Vol. 16 Issue 5 DOI 10.5195/jyd.2021.1061

Promoting Personal Growth

Mertens, D. M. (2007). Transformative Paradigm: Mixed Methods and Social Justice. Journal of Mixed Methods Research, 1(3), 212-225. (https://doi.org/10.1177/1558689807302811)

Morgan, D. L. (2014). Pragmatism as a paradigm for social research. Qualitative Inquiry, 20(8), 10451053. (https://doi.org/10.1177/1077800413513733)

Morton, M. H., Dworsky, A., Matjasko, J. L., Curry, S. R., Schlueter, D., Chávez, R., \& Farrell, A. F. (2018). Prevalence and correlates of youth homelessness in the United States. Journal of Adolescent Health, 62(1), 14-21. (https://doi.org/10.1016/j.jadohealth.2017.10.006)

Morton, M. H., Kugley, S., Epstein, R., \& Farrell, A. (2020). Interventions for youth homelessness: A systematic review of effectiveness studies. Children and Youth Services Review, 116(May). (https://doi.org/10.1016/j.childyouth.2020.105096)

Mygind, L., Kjeldsted, E., Hartmeyer, R., Mygind, E., Bølling, M., \& Bentsen, P. (2019). Mental, physical and social health benefits of immersive nature-experience for children and adolescents: A systematic review and quality assessment of the evidence. Health and Place, 58(October 2018), 102136. (https://doi.org/10.1016/j.healthplace.2019.05.014)

Norton, C. L., \& Watt, T. T. (2014). Exploring the impact of a wilderness-based positive youth development program for urban youth. Journal of Experiential Education, 3ᄌ4), 335-350. (https://doi.org/10.1177/1053825913503113)

Nowell, L. S., Norris, J. M., White, D. E., \& Moules, N. J. (2017). Thematic analysis: Striving to meet the trustworthiness criteria. International Journal of Qualitative Methods, 16(1). (https://doi.org/10.1177/1609406917733847)

O'Brien, K., \& Lomas, T. (2017). Developing a growth mindset through outdoor personal development: Can an intervention underpinned by psychology increase the impact of an outdoor learning course for young people? Journal of Adventure Education and Outdoor Learning, 17(2), 133-147. (https://doi.org/10.1080/14729679.2016.1232199)

Parry, B. J., Thompson. J. L., Holland, M. J. G., Cooley, S. J., Quinton, M. L., \& Cumming, J. (2021a). Health outcomes of physical activity-based positive youth development for disadvantaged young people: A systematic review [manuscript in preparation]. School of Sport, Exercise and Rehabilitation Sciences, University of Birmingham, UK.

Parry, B. J., Thompson. J. L., Holland, M. J. G., Quinton, M. L., \& Cumming, J. (2021b). Improving outcomes in young people experiencing homelessness with My Strengths Training for Life ${ }^{\mathrm{TM}}$ (MST4Life ${ }^{\mathrm{TM}}$ ): A qualitative realist evaluation. Children and Youth Services Review. 121, 105793 (https://doi.org/10.1016/j.childyouth.2020.105793)

Quinton, M. L., Clarke, F. J., Parry, B. J., \& Cumming, J. (2021). An evaluation of My Strengths Training for Life ${ }^{T M}$ for improving resilience and well-being of young people experiencing homelessness. Journal of Community Psychology, 1-19. (https://doi.org/10.1002/jcop.22517) 
Journal of Youth Development | http://jyd.pitt.edu/ | Vol. 16 Issue 5 DOI 10.5195/jyd.2021.1061

Promoting Personal Growth

Rew, L., Slesnick, N., Johnson, K., Aguilar, R., \& Cengiz, A. (2019). Positive attributes and life satisfaction in homeless youth. Children and Youth Services Review, 100(February), 1-8. (https://doi.org/10.1016/j.childyouth.2019.02.021)

Rice, E., Kurzban, S., \& Ray, D. (2012). Homeless but connected: the role of heterogeneous social network ties and social networking technology in the mental health outcomes of street-living adolescents. Community Mental Health Journal, 48(6), 692-698. (https://doi.org/10.1007/s10597-011-9462-1)

Rokach, A. (2005). The causes of loneliness in homeless youth. Journal of Psychology: Interdisciplinary and Applied, 139(5), 469-480. (https://doi.org/10.3200/JRLP.139.5.469-480)

Romm, N. (2014). Exploration of transformative paradigm with pragmatic twist to contribute to educational change. International Journal on New Trends in Education and Their Implications, 5(2), 12.

Roth, J. L., \& Brooks-Gunn, J. (2003). What is a youth development program? Identifying defining principles. In D. Wertlieb, F. Jacobs, \& R. M. Lerner (Eds.), Enhancing the life chances of youth and families: Public service systems and public policy perspectives: Handbook of applied developmental science: Promoting positive child, adolescent, and family development through research, policies, and progra (Vol. 2, pp. 197-224). SAGE Publications.

Russell, C. V., \& Bisson, C. (2003). Teaching group formation activities, group formation tools and group process tools. In S. Wurdinger and J. Steffen (Eds.), Developing challenge course programs for schools (pp. 103-138). Kendall Hunt.

Ryan, R. M., \& Deci, E. L. (2000). Self-determination theory and the facilitation of intrinsic motivation, social development, and wellbeing. The American Psychologist, 55, 68-78. (https://doi.org/doi:10.1037//0003-066x.55.1.68)

Sibthorp, J., \& Morgan, C. (2011). Adventure-based programming: exemplary youth development practice. New Directions for Youth Development, 2011(130), 105-119. (https://doi.org/10.1002/yd.400)

Sibthorp, J., Paisley, K., \& Gookin, J. (2007). Exploring participant development through adventure-based programming: a model from the National Outdoor Leadership School. Leisure Sciences, 29(1), 118. (https://doi.org/doi:10.1080/01490400600851346)

Smith, B., \& McGannon, K. R. (2018). Developing rigor in qualitative research: problems and opportunities within sport and exercise psychology. International Review of Sport and Exercise Psychology, 11(1), 101-121. (https://doi.org/10.1080/1750984X.2017.1317357)

Sproule, J., Martindale, R., Wang, J., Allison, P., Nash, C., \& Gray, S. (2013). Investigating the experience of outdoor and adventurous project work in an educational setting using a self-determination 
Journal of Youth Development | http://jyd.pitt.edu/ | Vol. 16 Issue 5 DOI 10.5195/jyd.2021.1061 Promoting Personal Growth

framework. European Physical Education Review, 19(3), 315-328.

(https://doi.org/10.1177/1356336X13495629)

Stepp, S. D., Pardini, D. A., Loeber, R., \& Morris, N. A. (2011). The relation between adolescent social competence and young adult delinquency and educational attainment among at-risk youth: The mediating role of peer delinquency. Canadian Journal of Psychiatry (Revue Canadienne de Psychiatrie), 56(8), 457-465. (https://doi.org/10.1177/070674371105600803)

Tidmarsh, G., Whiting, R. J., Thompson, J. L., \& Cumming, J. (2021). Assessing the fidelity of delivery style of a mental skills training programme for young people experiencing homelessness [manuscript submitted for publication]. School of Sport, Exercise and Rehabilitation Sciences, University of Birmingham, UK.

Tillmann, S., Tobin, D., Avison, W., \& Gilliland, J. (2018, June 27). Mental health benefits of interactions with nature in children and teenagers: A systematic review. Journal of Epidemiology and Community Health. BMJ Publishing Group. (https://doi.org/10.1136/jech-2018-210436)

Tracy, S. J. (2010). Qualitative quality: Eight a"big-tent" criteria for excellent qualitative research. Qualitative Inquiry, 16(10), 837-851. https://doi.org/10.1177/1077800410383121

Warren, K., Roberts, N. S., Breunig, M., \& Alvarez, M. A. G. (2014). Social justice in outdoor experiential education: A state of knowledge review. Journal of Experiential Education, 37, 1-15. (https://doi.org/doi:10.1177/1053825913518898)

Watson, J., \& Cuervo, H. (2017). Youth homelessness: A social justice approach. Journal of Sociology, 53(2), 461-475. (https://doi.org/10.1177/1440783317705204)

Young Minds. (2021). Coronavirus: Impact on young people with mental health needs Survey 4: February 2021. (https://youngminds.org.uk/media/4350/coronavirus-report-winter.pdf) 